\title{
The Effect of Temperature and Time Variables on Printing Quality in Sublimation Transfer Printing on Nylon and Polyester Fabric
}

\author{
Meral Özomay ${ }^{1,3 *}$, Zafer Özomay ${ }^{2,3}$ \\ ${ }^{1}$ Marmara University, Faculty of Technology, Department of Textile Engineering, Istanbul, Turkey, (ORCID: 0000-0003-0138-0060), meral.akkaya@marmara.edu.tr \\ ${ }^{2}$ Marmara University, School of Applied Sciences, Department of Printing Technologies, Istanbul, Turkey, (ORCID: 0000-0002-7650-733X), ozomay@marmara.edu.tr \\ ${ }^{3}$ Textile and Manuscripts Conservation and Restoration R \& D Laboratory, Marmara University, Istanbul, Turkey.
}

(First received 1 February 2021 and in final form 30 April 2021)

(DOI: $10.31590 /$ ejosat.889147)

ATIF/REFERENCE: Özomay, M. \& Özomay, Z. (2021). The Effect of Temperature and Time Variables on Printing Quality in Sublimation Transfer Printing on Nylon and Polyester Fabric European Journal of Science and Technology, (23), 882-891.

\begin{abstract}
The image on textile fabrics is created by various methods. The sublimation transfer printing method, which is one of the various image creation methods on fabric, was applied on nylon and polyester fabric in the study. The fabrics used were printed at two different temperatures, both $150^{\circ} \mathrm{C}$ and $200^{\circ} \mathrm{C}$, and with a pressing time of 30 seconds, 60 seconds, and 120 seconds. $\mathrm{L} *$ a $* \mathrm{~b} *$ values, wash fastness (staining and fading), delta E values of Cyan, Magenta, Yellow and Black colors, which are the process colors determined in the study, were measured alongside the analysis of fastness properties. It was determined that the image formation, pressing time and temperature-dependent fastness values on fabrics were $4 / 5$ (very good). Sublimation printing has shown that application differences depending on both temperature and time cause changes in color values. Considering the costs, it is suggested that the printing time of 30 seconds can be preferred, when compared to the longer printing time in sublimation prints.
\end{abstract}

Keywords: Sublimation Printing, Color, Washing Fastness, Fabric.

\section{Naylon ve Polyester Kumaş Üzerine Sublimasyon Transfer Baskıda Sıcaklık ve Süre Değişkeninin Baskı Kalitesine Etkisi}

$\ddot{O} \mathbf{z}$

Tekstil kumaşlar üzerine görüntü çok çeşitli yöntemler ile oluşturulmaktadır. Kumaş üzerine farklı görüntü oluşturma yöntemlerinden biri olan sublimasyon transfer baskı yöntemi çalışmada naylon ve polyester kumaş üzerine uygulanmıştır. Kullanılan kumaşlara hem $150^{\circ} \mathrm{C}$ hem de $200^{\circ} \mathrm{C}$ olmak üzere iki farklı sıcaklıkta ve $30 \mathrm{sn}, 60 \mathrm{sn}$ ve $120 \mathrm{sn}$ presleme süresi ile baskılar gerçekleştirilmiştir. Haslık özelliklerinin analizi ile birlikte çalışmada belirlenen proses renkler olan Cyan, Magenta, Yellow ve Black renklerinin; L* $\mathrm{a}^{*} \mathrm{~b}^{*}$ değerleri, yıkama haslığı (lekeleme ve solma), delta E değerleri ölçümlenmiştir. Kumaşlarda görüntü oluşumu presleme süresi ve sıcaklığa bağlı haslık değerleri 4/5 (çok iyi) olduğunu tespit edilmiştir. Süblimasyon baskı hem sıcaklığa hem de süreye bağlı uygulama farklılıklarının renk değerlerinde değişimler oluşturduğunu göstermiştir. İşletme maliyetleri de düşünüldüğünde sublime baskılarda 30 saniye baskı süresinin daha uzun baskı süresine göre tercih edilebileceği önerilmektedir.

Anahtar Kelimeler: Sublimasyon Baskı, Renk, Yıkama Haslı̆̆ı, Kumaş.

* Corresponding Author: ozomay@marmara.edu.tr 


\section{Introduction}

Today, polyester and nylon fibers are used instead of cotton and natural fibers (Bae, 2020). Polyester fibers are accepted all over the world due to their properties such as flexibility, high resistance, dimensional stability, resistance to many chemical compounds and low moisture absorption (Brady et al.,1980; Glombikova \& Komarkova, 2014).

Image transfer on polyester and nylon fabric is done with different methods (Cahill \& Ujiie, 2004). Screen printing on the fabric surface; is the transfer of ink transferred to digital printing or transfer paper to the fabric by pressing it through heat (Guan et al.,2009). Pre-processing is required to create an image on the fabric surface with digital and screen printing, and then pass through steam and fixing units to fix the ink (Hsieh \& Lin, 2018).
Sublimation (the physical process of transition from solid state to gaseous state) is the process of transferring the polymerrich pigment to a special transfer paper and adhering the image formed on the paper to the fabric fibers with pressure (Jin \& Sturm, 2010). In the sublimation thermal transfer printing system, using time, temperature and pressure, the image transfer is provided by the solid adhesion of the image on the film material on the substrate (Qihong \& Qinghua, 1997; Sahin et al., 2013). In the thermal transfer printing system, the important factor determining the printing quality is the printing parameters (temperature, pressure, time) and the substrate that will comply with them (Salem et al., 2013). Printing parameters determined in accordance with the surface properties of the substrate will give high printing quality.

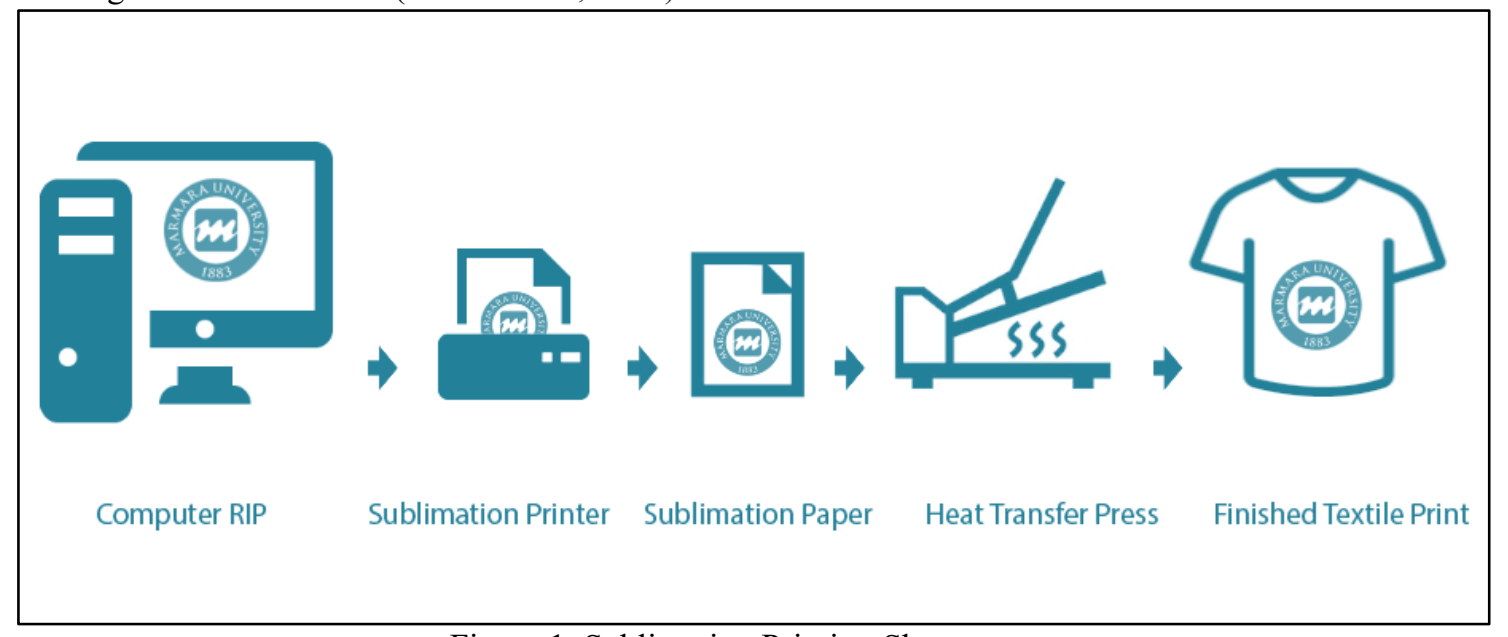

Figure 1. Sublimation Printing Sheme

In sublimation thermal transfer printing systems, it is primarily created on image transfer papers. The image is transferred on transfer papers by screen printing or digital Technologies (Sönmez et al., 2019). The image to be printed is created by transferring polymer pigment onto transfer printing papers. The pigment transferred to the transfer paper is microsized and solid. After the heat and pressure generated during printing, these polymer pigment particles in solid form on the transfer paper adhere to the substrate fibers. In this way, the image on the thermal paper is transferred to the substrate (Stojanović et al., 2020).

In the studies, instead of different types of fabrics such as cotton, wool, silk, fabrics developed due to their good chemical stability properties such as nylon and polyester are used (Yongqing, 2014). Surface modifications such as washing, light, anti-corrosion are the reasons why they are preferred (Zelenkova et al., 2020). Few studies have been conducted on the efficiency of sublimation transfer printing applications on textile fabrics. This research aims to determine the usability of the differences in washing, K / S, and color values after sublimation transfer printing formed on nylon and polyester fabric and their suitability in different applications (Wu \& Bai, 2011).

In the studies, instead of different types of fabrics such as cotton, wool, silk; nylon and polyester are used which are the fabrics developed due to their good chemical stability properties. Surface modifications such as washing, light, anti-corrosion are the reasons why they are preferred. Very few studies have been conducted on the efficiency of sublimation transfer printing applications on textile fabrics. In this research, the differences in washing, rubbing fastness, $\mathrm{K} / \mathrm{S}$ and color values after sublimation transfer printing on nylon and polyester fabric were determined.

\section{Material and Method}

\subsection{Materials}

In this study, two different fabrics, $100 \%$ polyester and $100 \%$ nylon, were used as materials. Technical features of these fabrics are given in Table 1.

Table 1. Technical properties of the fabrics used in the study

\begin{tabular}{l|c|c}
\hline Technical properties & Polyester & Nylon \\
\hline Fiber Type & $\% 100$ polyester & $\% 100$ nylon \\
\hline Woven Type & Plain weave & Plain weave \\
\hline Weight & $150 \mathrm{~g} / \mathrm{m}^{2}$ & $155 \mathrm{~g} / \mathrm{m}^{2}$ \\
\hline Warp density & $32 \mathrm{ends} / \mathrm{cm}$ & $33 \mathrm{ends} / \mathrm{cm}$ \\
\hline Weft Density & $32 \mathrm{ends} / \mathrm{cm}$ & $31 \mathrm{ends} / \mathrm{cm}$ \\
\hline$L$ & 88,77 & 88,92 \\
\hline$a$ & 1,54 & 1,15 \\
\hline$b$ & 12,36 & 7,95 \\
\hline
\end{tabular}

In this study, studies were carried out with CMYK colors by using ready-made disperse dyestuff formulations that can be sublimated. The dyestuffs used are shown in Table 2. 
Table 2: Technical characteristics of the inks used in the study

\begin{tabular}{|c|c|c|c|c|c|}
\hline Color & Manufacturer & Commercial Code & Light Fastness & Washing Fastness & Perspiration Fastness \\
\hline Cyan & \multirow{4}{*}{$\begin{array}{c}\text { Kian Digistar } \\
\text { Hi Pro }\end{array}$} & M501251 & $5-6$ & $4-5$ & $4-5$ \\
\hline Magenta & & M501230 & $6-7$ & $4-5$ & 5 \\
\hline Yellow & & M501215 & $6-7$ & $4-5$ & $4-5$ \\
\hline Black & & M501211 & 6 & $4-5$ & 5 \\
\hline
\end{tabular}

\subsection{Methods}

\subsubsection{Sublimation Transfer Printing Process}

The transfer printing material, for which a sublimation film layer is formed, has been conditioned in the printing room at a temperature range of $20-250{ }^{\circ} \mathrm{C}$ and a relative humidity of $40-60 \%$ for 24 hours before printing (Akkaya \& Eyupoglu, 2016). The main print films obtained were transferred on polyester and nylon textile fabrics using HP3803 flat thermal transfer printing machine at $150{ }^{\circ} \mathrm{C}, 200{ }^{\circ} \mathrm{C}$ with 30,60 and 120 seconds transfer waiting time.

\subsubsection{Color Measurement}

Printing and post-printing color measurement values were carried out using Datacolor color measurement device and Dyematch computer program. In the measurements, samples obtained by the conventional method were accepted as standard and measurements were carried out using a D / 65 light source under an observation angle of $10^{\circ}$.

Color differences with values of $\Delta E *, \Delta L *, \Delta a *, \Delta b *$, $\Delta C *$ and $\Delta H *$ were calculated using Formula 1, Formula 2, Formula 3, Formula 4, Formula 5, Formula 6.

$$
\begin{array}{ll}
\Delta E_{\mathrm{ab}}^{*}=\left(\Delta L^{* 2}+\Delta a^{* 2}+\Delta b^{* 2}\right)^{1 / 2} & \text { Formula 1 } \\
\Delta L^{* 2}=\left(L^{*}{ }_{2}-L^{*}\right)^{2} & \text { Formula 2 } \\
\Delta a^{* 2}=\left(a^{*}{ }_{2}-a_{1}\right)^{2} & \text { Formula 3 } \\
\Delta b^{* 2}=\left(b^{*}{ }_{2}-b^{*}\right)^{2} & \text { Formula 4 } \\
\Delta C^{*}{ }_{\mathrm{ab}}=\left(\left(a^{*}{ }_{2}-a^{*}\right)^{2}+\left(b^{*}{ }_{2}-b^{*}\right)^{2}\right)^{1 / 2} & \\
=\left(\Delta a^{* 2}+\Delta b^{* 2}\right)^{1 / 2} & \text { Formula 5 } \\
\Delta H^{*}=\left(\left(\Delta E^{*}{ }_{a b}\right)^{2}-\left(\Delta L^{*}\right)^{2}-\left(\Delta C^{*}\right)^{2}\right)^{1 / 2} & \text { Formula 6 }
\end{array}
$$

Color difference increases as $\Delta \mathrm{E}$ values (Ural et al., 2018) move away from $0 . \Delta L *$ indicates lightness - darkness, $a *$ indicates redness - greenery, $b *$ indicates yellowness - blueness, $\Delta \mathrm{C}$ indicates color intensity (tone angle), and $\Delta \mathrm{H} *$ indicates the difference between hue angles defined in the coordinate system (Hayta et. al., 2020; Özomay, 2009).

Color strength values $(\mathrm{K} / \mathrm{S})$ of the printed samples were calculated according to Formula 7 using Kubelka-Munk equation (Özomay \& Akalın, 2020; Akkaya \& Eyupoglu, 2016).

$$
K / S=(1-R)^{2} / 2 R
$$

Formula

In the formula, $K$ is the absorption coefficient, $S$ is the scattering coefficient, $R$ is the reflectance value of the fiber at the wavelength at maximum absorption, and $K / S$ is the color strength.

\subsubsection{Washing Fastness Test}

The washing fastnesses of the printed samples were made according to ISO 105-C06 standard using Gyrowash-James H. Heal brand washing fastness tester. Printed samples were processed with a washing fastness tester for 30 minutes at a temperature of $40^{\circ} \mathrm{C}$ in $1 / 100$ float, according to the ratio of $4 \mathrm{~g} / 1$ and evaluated with gray scale. In the application of the test, ECE non-ionic detergent was used according to the standard.

\section{Research Results and Discussion}

In this section, color measurement values, color differences and wash-light and rubbing fastnesses of the samples printed at different temperatures and times are evaluated.

\subsection{Color Measurement Results Dependent on Printing Temperature and Time}

CIE L*a*b* color values of cyan, magenta, yellow and black colors after sublimation printing of $100 \%$ polyester and $100 \%$ nylon fabrics are given in Table 3.

Table 3: Color measurement values of Cyan color samples with sublimation printing

\begin{tabular}{l|l|c|c|c|c|c|c}
\hline \multicolumn{2}{c}{ Cyan } & \multicolumn{3}{c|}{ Polyester } & \multicolumn{3}{c}{ Nylon } \\
\hline Temperature $\left({ }^{\circ} \mathrm{C}\right)$ & Time (min.) & L & $\mathrm{a}$ & $\mathrm{b}$ & $\mathrm{L}$ & $\mathrm{a}$ & $\mathrm{b}$ \\
\hline 150 & 30 & 61,81 & $-33,39$ & $-36,55$ & 62,7 & $-33,38$ & $-37,77$ \\
\hline 150 & 60 & 61,88 & $-33,58$ & $-36,55$ & 62,8 & $-33,27$ & $-37,7$ \\
\hline 150 & 120 & 61,63 & $-33,7$ & $-36,46$ & 63,52 & $-33,74$ & $-37,66$ \\
\hline 200 & 30 & 62,21 & $-33,88$ & $-35,77$ & 63,95 & $-34,3$ & $-37,39$ \\
\hline 200 & 60 & 62,42 & $-33,83$ & $-35,47$ & 64,09 & $-34,14$ & $-37,29$ \\
\hline 200 & 120 & 62,21 & $-33,89$ & $-35,87$ & 64,14 & $-34,64$ & $-37,27$ \\
\hline
\end{tabular}


It is seen that there is a significant and regular increase in the CIE $\mathrm{L}^{*}$ value due to the increase in temperature and printing time in cyan color printing on polyester and nylon fabrics. The increase in the CIE $\mathrm{L} *$ value indicates that the samples with a printing temperature of $200{ }^{\circ} \mathrm{C}$ are lighter. In addition, it is understood that cyan color prints made on polyester fabric are darker than prints made on nylon fabric.
There was no change in CIE $\mathrm{a} *$ and CIE $\mathrm{b} *$ values depending on the printing time for both polyester and nylon fabrics. It is seen that the samples printed at $150{ }^{\circ} \mathrm{C}$ in the prints made on polyester fabric shifted to blue more than the samples printed at $200^{\circ} \mathrm{C}$, and the increase in printing temperature in the prints made on nylon fabric shifted the samples to green nuance.

Table 4. Color measurement values of Magenta color samples with sublimation printing

\begin{tabular}{l|l|c|c|c|c|c|c}
\hline & \multicolumn{3}{c|}{ Molyester } & \multicolumn{3}{c}{ Nylon } \\
\hline Temperature $\left({ }^{\circ} \mathrm{C}\right)$ & Time (min.) & L & $\begin{array}{c}\text { Temperature } \\
\left({ }^{\circ} \mathrm{C}\right)\end{array}$ & $\begin{array}{c}\text { Time } \\
(\mathrm{min} .)\end{array}$ & $\mathrm{L}$ & $\begin{array}{c}\text { Temperature } \\
\left({ }^{\circ} \mathrm{C}\right)\end{array}$ & $\begin{array}{c}\text { Time } \\
(\mathrm{min} .)\end{array}$ \\
\hline 150 & 30 & 50,79 & 60,66 & $-1,27$ & 51,42 & 61,18 & $-2,41$ \\
\hline 150 & 60 & 51,16 & 60,66 & $-1,66$ & 51,6 & 61,05 & $-2,46$ \\
\hline 150 & 120 & 51,04 & 60,58 & $-1,38$ & 52,13 & 61,2 & $-3,04$ \\
\hline 200 & 30 & 51,91 & 59,23 & $-2,91$ & 52,81 & 60,4 & $-4,08$ \\
\hline 200 & 60 & 53,9 & 57,3 & $-5,6$ & 54,56 & 58,94 & $-6,18$ \\
\hline 200 & 120 & 55,52 & 54,91 & $-8,09$ & 57,5 & 55,45 & $-9,81$ \\
\hline
\end{tabular}

When Table 4 is examined, it is seen that there is a significant increase in the CIE $\mathrm{L} *$ value due to the increase in temperature and printing time in magenta color printing on polyester and nylon fabrics. The increase in the CIE $\mathrm{L} *$ value indicates that the samples with a printing temperature of $200{ }^{\circ} \mathrm{C}$ are lighter. In addition, it is understood that the cyan color prints made on polyester fabric are darker than the prints made on nylon fabric.
There was no change depending on the printing time for both polyester and nylon fabrics in the prints made at $150{ }^{\circ} \mathrm{C}$ in $\mathrm{CIE}$ a $*$ and $\mathrm{CIE} \mathrm{b} *$ values. In the prints made at $200{ }^{\circ} \mathrm{C}$ in $\mathrm{CIE} \mathrm{a} *$ and $\mathrm{CIE} \mathrm{b} *$ values, as the printing time decreases, magenta prints made on polyester fabrics have a color deviation towards red; As the printing time increases, it is concluded that the color shifts towards blue.

Table 5: Color measurement values of Yellow color samples with sublimation printing

\begin{tabular}{l|l|c|c|c|c|c|c}
\hline \multicolumn{2}{c|}{ Yellow } & \multicolumn{3}{c|}{ Polyester } & \multicolumn{3}{c}{ Nylon } \\
\hline Temperature $\left({ }^{\circ} \mathrm{C}\right)$ & Time (min.) & L & a & b & L & a & b \\
\hline 150 & 30 & 86,15 & $-2,98$ & 82,93 & 87,03 & $-3,22$ & 82,73 \\
\hline 150 & 60 & 86,41 & $-2,9$ & 82,78 & 87,19 & $-3,18$ & 82,91 \\
\hline 150 & 120 & 86,24 & $-2,79$ & 82,24 & 87,72 & $-3,29$ & 82,87 \\
\hline 200 & 30 & 86,13 & $-3,03$ & 80,9 & 87,74 & $-3,33$ & 81,83 \\
\hline 200 & 60 & 86,26 & $-3,02$ & 79,37 & 88,22 & $-3,58$ & 80,32 \\
\hline 200 & 120 & 85,96 & $-3,35$ & 77,35 & 88,03 & $-3,62$ & 77,49 \\
\hline
\end{tabular}

A significant and regular increase in the $\mathrm{CIE} \mathrm{L} *$ value due to the increase in temperature and printing time in yellow color printing applied to nylon fabrics, in other words, the color was in lighter shades, while no significant change occurred in the CIE L
* value in polyester fabric. In addition, it is seen that the yellow nuance of the color increases as the printing time decreases in the prints made at $200{ }^{\circ} \mathrm{C}$ in both polyester and nylon fabrics.

Table 6. Color measurement values of Black color samples with sublimation printing

\begin{tabular}{l|l|l|l|l|c|c|c}
\hline \multicolumn{2}{c|}{ Black } & \multicolumn{3}{c|}{ Polyester } & \multicolumn{3}{c}{ Nylon } \\
\hline Temperature $\left({ }^{\circ} \mathrm{C}\right)$ & $\begin{array}{c}\text { Time } \\
(\mathrm{min} .)\end{array}$ & $\mathrm{L}$ & $\mathrm{a}$ & $\mathrm{b}$ & $\mathrm{L}$ & $\mathrm{a}$ & $\mathrm{b}$ \\
\hline 150 & 30 & 30,65 & 0,63 & 2,39 & 30,62 & 0,11 & 0,97 \\
\hline 150 & 60 & 29,86 & 0,17 & 1,43 & 30,32 & 0,58 & 1,49 \\
\hline 150 & 120 & 29,76 & 0,74 & 2,51 & 30,39 & 0,65 & 1,39 \\
\hline 200 & 30 & 31,24 & 0,89 & 2,63 & 30,96 & 0,81 & 1,56 \\
\hline 200 & 60 & 31,5 & 1,07 & 2,58 & 31,84 & 1,03 & 1,83 \\
\hline 200 & 120 & 31,15 & 1,05 & 2,55 & 31,88 & 1,64 & 1,9 \\
\hline
\end{tabular}


The fading of the color tone due to the temperature increase in the colors of cyan, magenta and yellow was again realized in both polyester and nylon fabrics for Black color. However, unlike other colors, there was no significant difference between the prints made on polyester and nylon fabric in terms of darkness and lightness in black. Increasing the printing temperature in black color prints made on polyester and nylon fabrics indicates a positive increase in the CIE a * value of the color, that is, the color has shifted towards red. While the CIE $b *$ value did not change significantly in polyester fabric due to temperature and time, it was observed that the yellowness value of the color increased with the temperature and time-dependent increases in black color prints made on nylon fabric.

\subsection{Color Measurement Differences Depending on Printing Temperature and Time}

The $\Delta \mathrm{E}, \Delta \mathrm{L}, \Delta \mathrm{a}, \Delta \mathrm{b}, \Delta \mathrm{C}$ and $\Delta \mathrm{H}$ values for cyan, magenta, yellow and black colors after sublimation printing of $100 \%$ polyester and $100 \%$ nylon fabrics are calculated according to Formula 1 and are given in Tables 7-8-9 and 10. According to the tables, while calculating the color differences in the samples printed at $150{ }^{\circ} \mathrm{C}$, the prints made in 30 seconds were taken as reference, while calculating the color differences in the samples printed at $200{ }^{\circ} \mathrm{C}$, the prints made at the same temperature in 30 seconds were taken as reference. In the prints made on nylon fabrics, the prints made at the same temperatures in 30 seconds are used as a reference.

Table 7. $\Delta E *, \Delta L^{*}, \Delta a *, \Delta b^{*}, \Delta C^{*}$ and $\Delta H^{*}$ Values of Cyan color printed samples

\begin{tabular}{|c|c|c|c|c|c|c|c|c|}
\hline CYAN & Temperature $\left({ }^{\circ} \mathrm{C}\right)$ & $\begin{array}{l}\text { Time } \\
\text { (min.) }\end{array}$ & $\Delta \mathbf{E}$ & $\Delta \mathbf{L}$ & $\Delta \mathbf{a}$ & $\Delta \mathbf{b}$ & $\Delta \mathrm{C}$ & $\Delta \mathbf{H}$ \\
\hline \multirow{4}{*}{ Polyester } & 150 & 60 & 0,10 & 0,07 & 0,19 & 0,00 & 0,1 & 0,1 \\
\hline & 150 & 120 & 0,21 & 0,18 & 0,31 & 0,09 & 0,1 & 0,3 \\
\hline & 200 & 60 & 0,21 & 0,21 & 0,05 & 0,30 & 0,3 & 0,2 \\
\hline & 200 & 120 & 0,04 & 0,00 & 0,01 & 0,10 & 0,1 & 0,1 \\
\hline \multirow{4}{*}{ Nylon } & 150 & 60 & 0,09 & 0,10 & 0,11 & 0,07 & 0,1 & 0,0 \\
\hline & 150 & 120 & 0,71 & 0,82 & 0,36 & 0,11 & 0,2 & 0,3 \\
\hline & 200 & 60 & 0,13 & 0,14 & 0,16 & 0,10 & 0,2 & 0,1 \\
\hline & 200 & 120 & 0,23 & 0,19 & 0,34 & 0,12 & 0,1 & 0,3 \\
\hline
\end{tabular}

When Table 7 is examined, it is seen that the color differences calculated according to the printing time of 30 seconds of all categories are almost the same and very low. Therefore, it is concluded that increasing the printing time will not affect the color for cyan color. Considering the importance of time in terms of costs in businesses, it is predicted that 30 seconds of printing time will save time and reduce unnecessary costs.

Table 8. $\Delta E^{*}, \Delta L^{*}, \Delta a^{*}, \Delta b^{*}, \Delta C^{*}$ and $\Delta H^{*}$ Values of Magenta color printed samples

\begin{tabular}{|c|c|c|c|c|c|c|c|c|}
\hline MAGENTA & Temperature $\left({ }^{\circ} \mathrm{C}\right)$ & $\begin{array}{c}\text { Time } \\
\text { (min.) }\end{array}$ & $\Delta \mathbf{E}$ & $\Delta \mathbf{L}$ & $\Delta \mathbf{a}$ & $\Delta \mathbf{b}$ & $\Delta \mathrm{C}$ & $\Delta \mathbf{H}$ \\
\hline \multirow{4}{*}{ Polyester } & 150 & 60 & 0,41 & 0,37 & 0,00 & 0,39 & 0,0 & 0,4 \\
\hline & 150 & 120 & 0,26 & 0,25 & 0,08 & 0,11 & 0,1 & 0,1 \\
\hline & 200 & 60 & 2,37 & 1,99 & 1,93 & 2,69 & 1,7 & 2,8 \\
\hline & 200 & 120 & 4,44 & 3,61 & 4,32 & 5,18 & 3,8 & 5,6 \\
\hline \multirow{4}{*}{ Nylon } & 150 & 60 & 0,18 & 0,18 & 0,13 & 0,05 & 0,1 & 0,1 \\
\hline & 150 & 120 & 0,76 & 0,71 & 0,02 & 0,63 & 0,0 & 0,6 \\
\hline & 200 & 60 & 1,99 & 1,75 & 1,46 & 2,10 & 1,3 & 2,2 \\
\hline & 200 & 120 & 5,37 & 4,69 & 4,95 & 5,73 & 4,2 & 6,3 \\
\hline
\end{tabular}

According to the color differences table calculated with reference to the shortest printing time in each category for magenta color, it has been determined that the printing time of polyester and nylon fabrics at $150^{\circ} \mathrm{C}$ does not have a significant effect on color differences. However, in prints made at $200{ }^{\circ} \mathrm{C}$, it is seen that the color difference increases as the printing time increases. The E color differences that occur in the printing of polyester and nylon fabrics at $200{ }^{\circ} \mathrm{C}$ vary between 2 and 5. This change is a change that can be perceived with the eye. At the same time, the increase in printing time caused an increase in $\Delta \mathrm{C}$ value, making the magenta colors more vivid. 
Table 9. $\Delta E^{*}, \Delta L^{*}, \Delta a *, \Delta b^{*}, \Delta C^{*}$ and $\Delta H^{*}$ Values of Yellow color printed samples

\begin{tabular}{|c|c|c|c|c|c|c|c|c|}
\hline YELLOW & Temperature $\left({ }^{\circ} \mathrm{C}\right)$ & Time (min.) & $\Delta \mathbf{E}$ & $\Delta \mathbf{L}$ & $\Delta \mathbf{a}$ & $\Delta \mathbf{b}$ & $\Delta \mathrm{C}$ & $\Delta \mathbf{H}$ \\
\hline \multirow{4}{*}{ Polyester } & 150 & 60 & 0,18 & 0,26 & 0,08 & 0,15 & 0,2 & 0,1 \\
\hline & 150 & 120 & 0,18 & 0,09 & 0,19 & 0,69 & 0,7 & 0,2 \\
\hline & 200 & 60 & 0,34 & 0,13 & 0,01 & 1,53 & 1,5 & 0,0 \\
\hline & 200 & 120 & 0,83 & 0,17 & 0,32 & 3,55 & 3,5 & 0,5 \\
\hline \multirow{4}{*}{ Nylon } & 150 & 60 & 0,11 & 0,16 & 0,04 & 0,18 & 0,2 & 0,0 \\
\hline & 150 & 120 & 0,45 & 0,69 & 0,07 & 0,14 & 0,1 & 0,1 \\
\hline & 200 & 60 & 0,48 & 0,48 & 0,25 & 1,51 & 1,5 & 0,3 \\
\hline & 200 & 120 & 1,00 & 0,29 & 0,29 & 4,34 & 4,3 & 0,5 \\
\hline
\end{tabular}

When Table 9 is examined, it is seen that the color differences calculated according to the 30 second printing time of all categories are very low and almost the same. When the results of $\Delta \mathrm{L} *, \Delta \mathrm{a} *, \Delta \mathrm{b} *, \Delta \mathrm{C} *$ and $\Delta \mathrm{H} *$ are examined separately, it is seen that $\Delta \mathrm{b} *, \Delta \mathrm{C} *$ is slightly affected in the prints made on both polyester and nylon fabrics, but this effect does not cause a serious change in $\mathrm{E} *$. Therefore, it is concluded that increasing the printing time will not affect the color for yellow color. Considering the importance of time in terms of costs in businesses, the printing time is 30 seconds. It is predicted that doing with it will save time and reduce unnecessary costs.

Table 10. $\Delta E^{*}, \Delta L^{*}, \Delta a *, \Delta b^{*}, \Delta C *$ and $\Delta H^{*}$ Values of Black color printed samples

\begin{tabular}{|c|c|c|c|c|c|c|c|c|}
\hline BLACK & Temperature $\left({ }^{\circ} \mathrm{C}\right)$ & Time (min.) & $\Delta \mathbf{E}$ & $\Delta \mathbf{L}$ & $\Delta \mathbf{a}$ & $\Delta \mathbf{b}$ & $\Delta C$ & $\Delta \mathbf{H}$ \\
\hline \multirow{4}{*}{ Polyester } & 150 & 60 & 0,54 & 0,79 & 0,46 & 0,96 & 1,0 & 0,3 \\
\hline & 150 & 120 & 0,28 & 0,89 & 0,11 & 0,12 & 0,1 & 0,1 \\
\hline & 200 & 60 & 0,32 & 0,26 & 0,18 & 0,05 & 0,0 & 0,2 \\
\hline & 200 & 120 & 0,19 & 0,09 & 0,16 & 0,08 & 0,0 & 0,2 \\
\hline \multirow{4}{*}{ Nylon } & 150 & 60 & 0,76 & 0,30 & 0,47 & 0,52 & 0,6 & 0,3 \\
\hline & 150 & 120 & 0,72 & 0,23 & 0,54 & 0,42 & 0,6 & 0,4 \\
\hline & 200 & 60 & 0,97 & 0,88 & 0,22 & 0,27 & 0,3 & 0,1 \\
\hline & 200 & 120 & 0,95 & 0,92 & 0,83 & 0,34 & 0,8 & 0,5 \\
\hline
\end{tabular}

It is seen that the color differences calculated according to the printing time of 30 seconds for all categories for black color are almost the same and very low as in the cyan color. Therefore, it is concluded that increasing the printing time will not affect the color for black color. Considering the importance of time in terms of costs in businesses, the printing time is 30 seconds. It is predicted that doing with it will save time and reduce unnecessary costs.

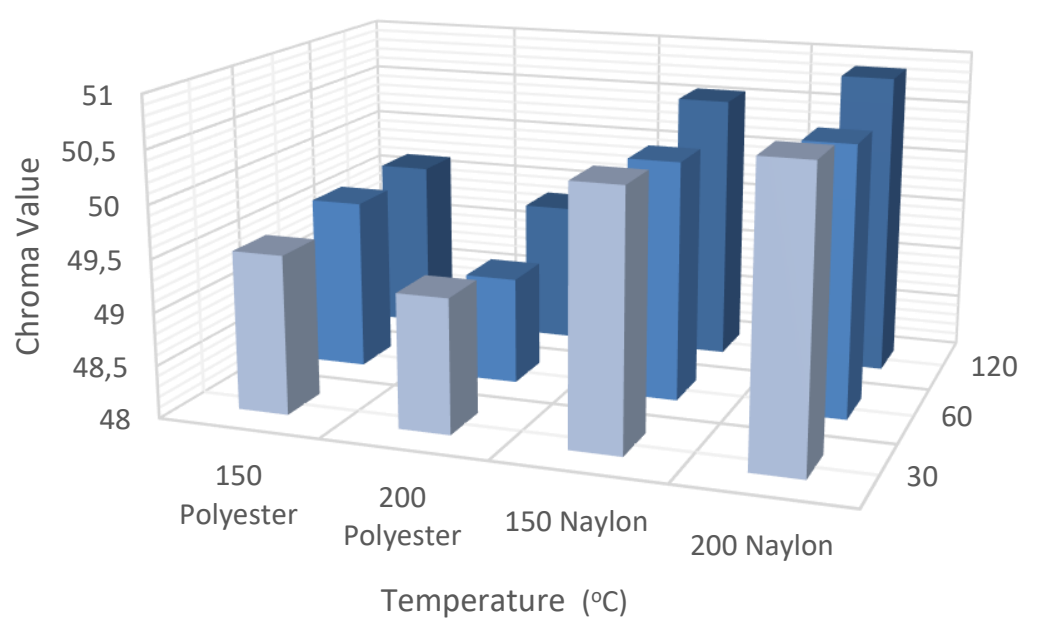

Figure 2. Chroma values of Cyan color printed samples 
In visual color perception, Chroma expresses the vibrancy or opacity properties of a color. A positive chroma value indicates that the color has a higher saturation. When the Crome values of the Cyan color are examined according to Figure 2, it has been determined that the prints made on nylon fabric have a higher saturation than the printing colors on polyester fabric, hence more vivid colors. In terms of printing temperature and time, it is seen that the colors of the prints made in 120 seconds between all prints are more vivid compared to other times.

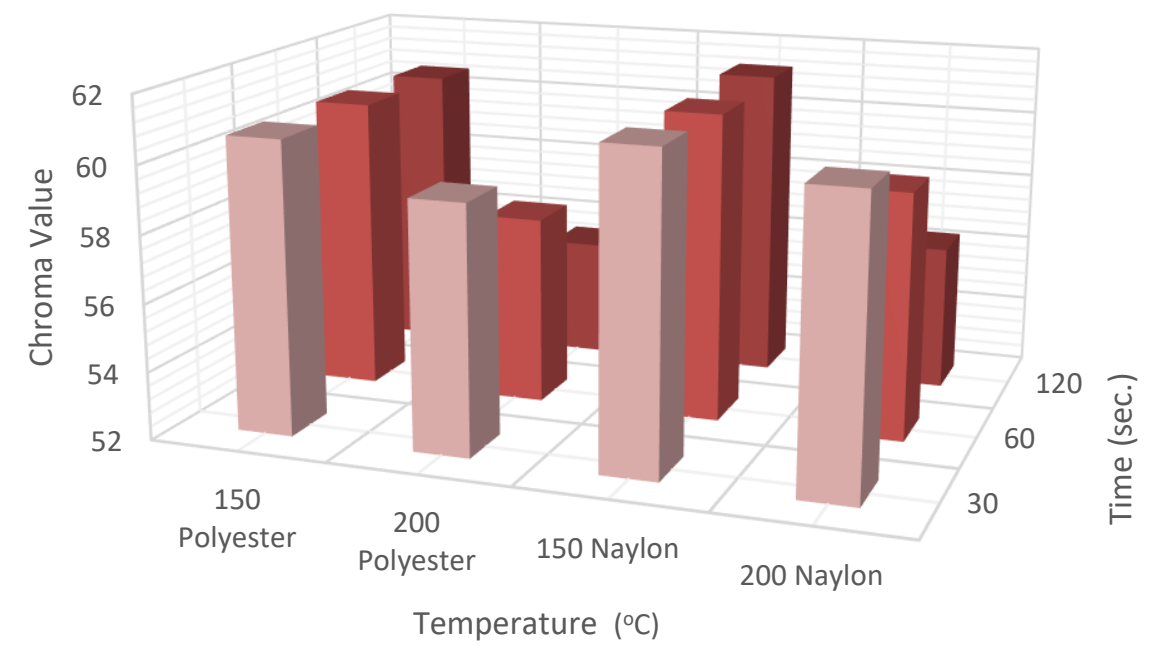

Figure 3. Chroma values of Magenta color printed samples

When the Crome values of Magenta color are examined according to Figure 3, it was determined that the prints made on nylon fabric have more vivid colors than the printing colors on polyester fabric. While there is no significant difference between them in terms of chroma value as printing times change in magenta color's prints at $150{ }^{\circ} \mathrm{C}$; In the prints made on both fabrics at $200{ }^{\circ} \mathrm{C}$, it is seen that the gray ratio increases as the printing time increases, so the color becomes dull.

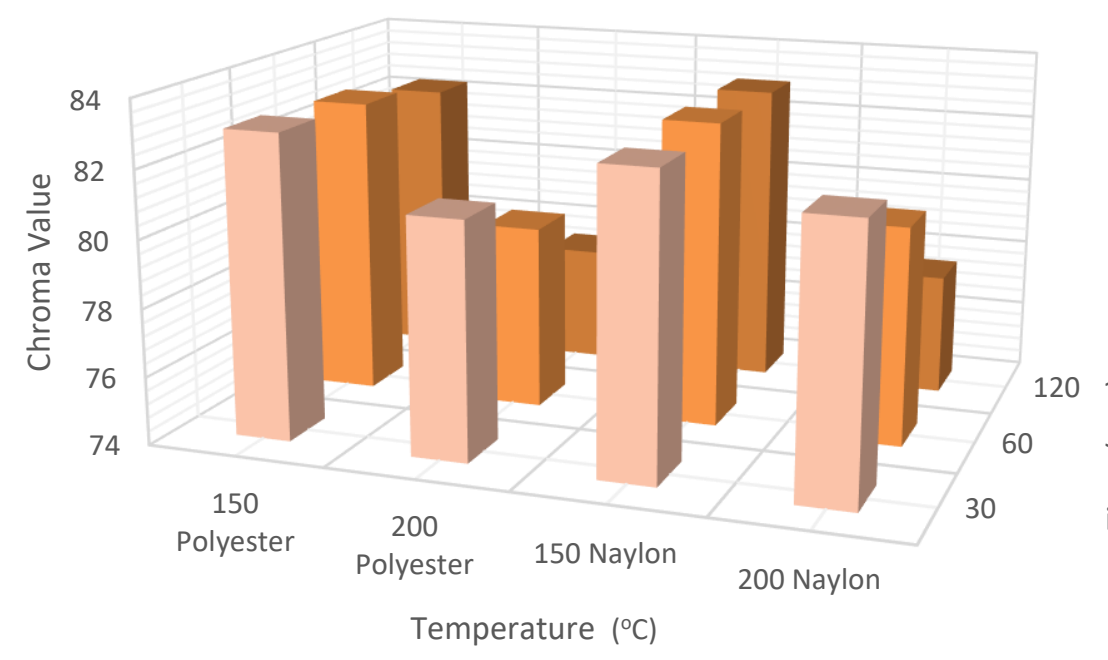

Figure 4. Chroma values of Yellow color printed samples

When the Crome values of the yellow color were examined, no significant difference was found between nylon and polyester fabrics in the prints made at the same temperature and time.
However, in the prints of Yellow color on both fabrics at $200{ }^{\circ} \mathrm{C}$, it is seen that the gray ratio increases as the printing time increases, so the color becomes dull. 


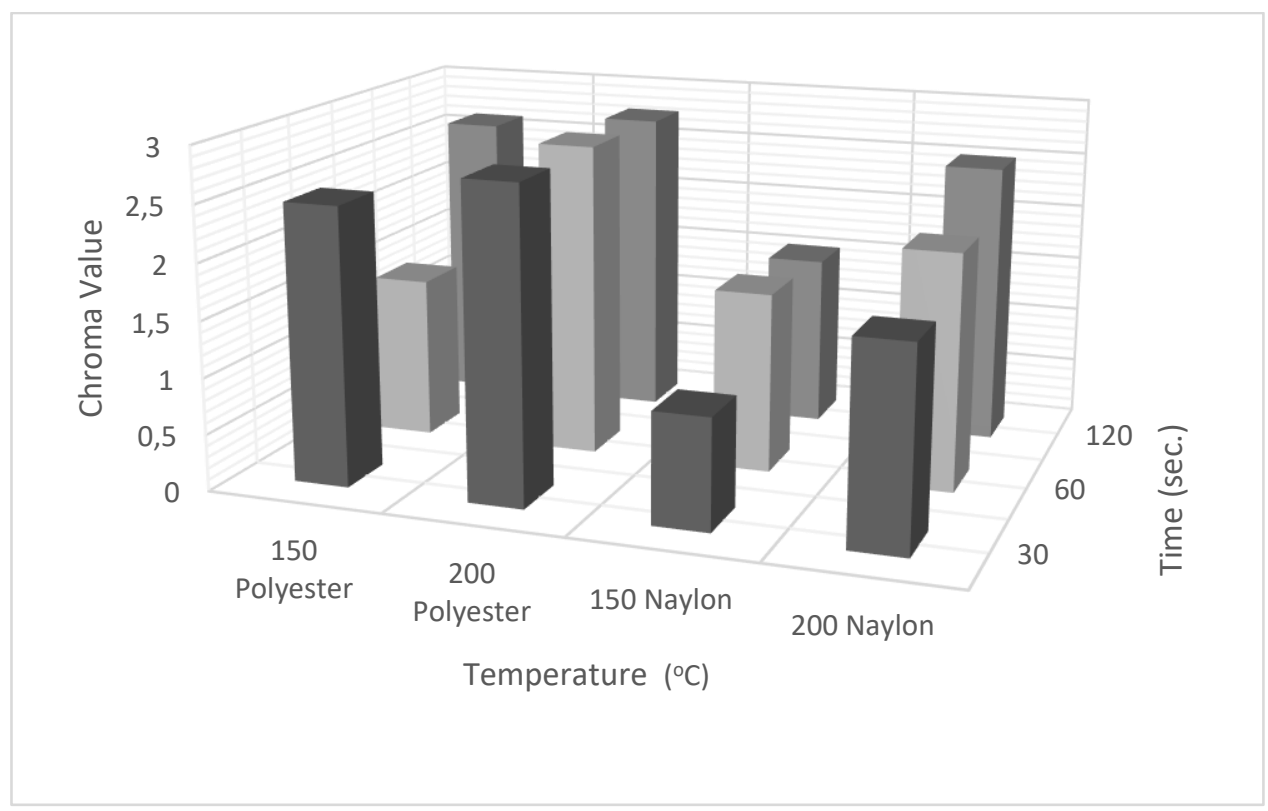

Figure 5: Chroma values of black color printed samples

When the Crome values of Black color are examined according to Figure 5, it is seen that, unlike other colors, black color prints made on polyester fabric have generally more vivid colors than black color prints made on nylon fabric. While the print with the lowest value in terms of color saturation is the sample printed at $150{ }^{\circ} \mathrm{C}$ for 30 seconds on nylon fabric; the printing with the most vivid colors was found to be the printing made on polyester fabric at $200{ }^{\circ} \mathrm{C}$ in 60 seconds.

\subsection{Washing Fastness Analysis Based on Printing Temperature and Time}

Table 11: Washing fastness results

\begin{tabular}{|c|c|c|c|c|c|c|c|c|c|c|}
\hline$\frac{\grave{\theta}}{\dot{\theta}}$ & 包 & 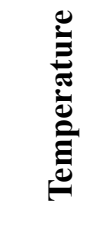 & 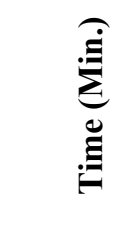 & 䒕 & 巳゙ & $\begin{array}{l}b \\
\dot{b} \\
\overline{0} \\
\frac{0}{\lambda} \\
\bar{z}\end{array}$ & 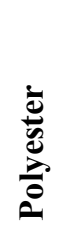 & $\frac{e}{2}$ & $\overline{8}$ & 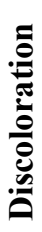 \\
\hline \multirow{12}{*}{ 齐 } & \multirow{6}{*}{ 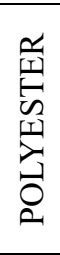 } & 150 & 30 & 5 & 5 & 5 & 5 & 5 & 5 & 5 \\
\hline & & 150 & 60 & 5 & 5 & 5 & 5 & 5 & 5 & 5 \\
\hline & & 150 & 120 & $4 / 5$ & $4 / 5$ & $4 / 5$ & $4 / 5$ & $4 / 5$ & $4 / 5$ & 5 \\
\hline & & 200 & 30 & 5 & 5 & 5 & 5 & 5 & 5 & 5 \\
\hline & & 200 & 60 & $4 / 5$ & $4 / 5$ & $4 / 5$ & $4 / 5$ & $4 / 5$ & $4 / 5$ & 5 \\
\hline & & 200 & 120 & $4 / 5$ & $4 / 5$ & $4 / 5$ & $4 / 5$ & $4 / 5$ & $4 / 5$ & 5 \\
\hline & \multirow{6}{*}{$\begin{array}{l}Z \\
\vdots \\
z \\
z\end{array}$} & 150 & 30 & 5 & 5 & 5 & 5 & 5 & 5 & 5 \\
\hline & & 150 & 60 & $4 / 5$ & $4 / 5$ & $4 / 5$ & $4 / 5$ & $4 / 5$ & $4 / 5$ & 5 \\
\hline & & 150 & 120 & 5 & 5 & 5 & 5 & 5 & 5 & 5 \\
\hline & & 200 & 30 & 5 & 5 & 5 & 5 & 5 & 5 & 5 \\
\hline & & 200 & 60 & $4 / 5$ & $4 / 5$ & $4 / 5$ & $4 / 5$ & $4 / 5$ & $4 / 5$ & 5 \\
\hline & & 200 & 120 & 5 & 5 & 5 & 5 & 5 & 5 & 5 \\
\hline \multirow{12}{*}{ 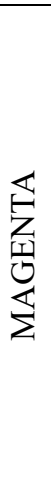 } & \multirow{6}{*}{ 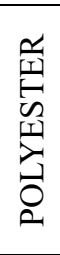 } & 150 & 30 & 5 & 5 & 5 & 5 & 5 & 5 & 5 \\
\hline & & 150 & 60 & $4 / 5$ & $4 / 5$ & $4 / 5$ & $4 / 5$ & $4 / 5$ & $4 / 5$ & 5 \\
\hline & & 150 & 120 & 5 & 5 & 5 & 5 & 5 & 5 & 5 \\
\hline & & 200 & 30 & 5 & 5 & 5 & 5 & 5 & 5 & 5 \\
\hline & & 200 & 60 & $4 / 5$ & $4 / 5$ & $4 / 5$ & $4 / 5$ & $4 / 5$ & $4 / 5$ & 5 \\
\hline & & 200 & 120 & $4 / 5$ & $4 / 5$ & $4 / 5$ & $4 / 5$ & $4 / 5$ & $4 / 5$ & 5 \\
\hline & \multirow{6}{*}{$\begin{array}{l}z \\
\vdots \\
z \\
z\end{array}$} & 150 & 30 & 5 & 5 & 5 & 5 & 5 & 5 & 5 \\
\hline & & 150 & 60 & $4 / 5$ & $4 / 5$ & $4 / 5$ & $4 / 5$ & $4 / 5$ & $4 / 5$ & 5 \\
\hline & & 150 & 120 & 5 & 5 & 5 & 5 & 5 & 5 & 5 \\
\hline & & 200 & 30 & 5 & 5 & 5 & 5 & 5 & 5 & 5 \\
\hline & & 200 & 60 & 5 & 5 & 5 & 5 & 5 & 5 & 5 \\
\hline & & 200 & 120 & 5 & $4 / 5$ & 5 & 5 & $4 / 5$ & $4 / 5$ & 5 \\
\hline
\end{tabular}




\begin{tabular}{|c|c|c|c|c|c|c|c|c|c|c|}
\hline \multirow{12}{*}{ 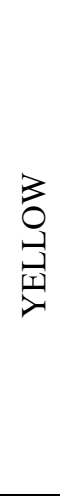 } & \multirow{6}{*}{ 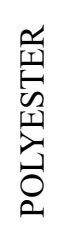 } & 150 & 30 & 5 & 5 & 5 & 5 & 5 & 5 & 5 \\
\hline & & 150 & 60 & $4 / 5$ & $4 / 5$ & $4 / 5$ & $4 / 5$ & $4 / 5$ & $4 / 5$ & 5 \\
\hline & & 150 & 120 & $4 / 5$ & $4 / 5$ & $4 / 5$ & $4 / 5$ & $4 / 5$ & $4 / 5$ & 5 \\
\hline & & 200 & 30 & 5 & 5 & 5 & 5 & 5 & 5 & 5 \\
\hline & & 200 & 60 & $4 / 5$ & $4 / 5$ & $4 / 5$ & $4 / 5$ & $4 / 5$ & $4 / 5$ & 5 \\
\hline & & 200 & 120 & $4 / 5$ & $4 / 5$ & $4 / 5$ & $4 / 5$ & $4 / 5$ & $4 / 5$ & 5 \\
\hline & & 150 & 30 & 5 & 5 & 5 & 5 & 5 & 5 & 5 \\
\hline & & 150 & 60 & $4 / 5$ & $4 / 5$ & $4 / 5$ & $4 / 5$ & $4 / 5$ & $4 / 5$ & 5 \\
\hline & 0 & 150 & 120 & 5 & 5 & 5 & 5 & 5 & 5 & 5 \\
\hline & $\bar{\nabla}$ & 200 & 30 & 5 & 5 & 5 & 5 & 5 & 5 & 5 \\
\hline & & 200 & 60 & 5 & 5 & 5 & 5 & 5 & 5 & 5 \\
\hline & & 200 & 120 & $4 / 5$ & $4 / 5$ & $4 / 5$ & $4 / 5$ & $4 / 5$ & $4 / 5$ & 5 \\
\hline & & 150 & 30 & 5 & 5 & 5 & 5 & 5 & 5 & 5 \\
\hline & 立 & 150 & 60 & 5 & 5 & 5 & 5 & 5 & 5 & 5 \\
\hline & 5 & 150 & 120 & $4 / 5$ & $4 / 5$ & $4 / 5$ & $4 / 5$ & $4 / 5$ & $4 / 5$ & 5 \\
\hline & $\bar{\lambda}$ & 200 & 30 & 5 & 5 & 5 & 5 & 5 & 5 & 5 \\
\hline & $\overrightarrow{0}$ & 200 & 60 & $4 / 5$ & $4 / 5$ & $4 / 5$ & $4 / 5$ & $4 / 5$ & $4 / 5$ & 5 \\
\hline $\bar{T}$ & & 200 & 120 & $4 / 5$ & $4 / 5$ & $4 / 5$ & $4 / 5$ & $4 / 5$ & $4 / 5$ & 5 \\
\hline 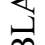 & & 150 & 30 & 5 & 5 & 5 & 5 & 5 & 5 & 5 \\
\hline & & 150 & 60 & $4 / 5$ & $4 / 5$ & $4 / 5$ & $4 / 5$ & $4 / 5$ & $4 / 5$ & 5 \\
\hline & 0 & 150 & 120 & $4 / 5$ & $4 / 5$ & $4 / 5$ & $4 / 5$ & $4 / 5$ & $4 / 5$ & 5 \\
\hline & 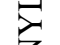 & 200 & 30 & 5 & 5 & 5 & 5 & 5 & 5 & 5 \\
\hline & & 200 & 60 & 5 & 5 & 5 & 5 & 5 & 5 & 5 \\
\hline & & 200 & 120 & $4 / 5$ & $4 / 5$ & $4 / 5$ & $4 / 5$ & $4 / 5$ & $4 / 5$ & 5 \\
\hline
\end{tabular}

Washing fastness of $100 \%$ polyester and $100 \%$ nylon fabrics after sublimation printing was examined separately for cyan, magenta, yellow and black colors. According to Table 15, it has been concluded that there is no significant difference between the colors according to the variables of temperature and printing time.

\section{Conclusion}

When the color values of the samples are examined, it is seen that the CIE L * values of all samples increase between $150{ }^{\circ} \mathrm{C}$ and $200^{\circ} \mathrm{C}$ after sublimation printing. The increase in the CIE L * value indicates that the samples with a printing temperature of $200{ }^{\circ} \mathrm{C}$ are lighter.

When the polyester and nylon fabrics printed under the same conditions are compared, the increase in the CIE $\mathrm{L} *$ value shows that the prints made on the nylon fabric are in lighter shades.

For cyan, magenta and black colors, it is concluded that the $\Delta \mathrm{E}$ color differences calculated according to the 30 second printing time of all categories are very low, so increasing the printing time does not affect the color positively or negatively.

It has been determined that the colors of the prints made on nylon fabric in Cyan, Magenta and Yellow colors are more vivid than the printing colors on polyester fabric, while the fabric with more vivid colors in black is polyester.

It has been determined that all colors have very good fading values after washing fastness. Again, at different printing temperatures of all colors, 30 seconds. It is concluded that the staining results are very good in prints made with the printing time.

As a result, it is suggested that a 30 -second printing time can be preferred in sublimation prints, considering the operating costs, since there is no negative difference in colors compared to the
It is seen that the prints of all colors and temperatures in 30 seconds printing time are the prints that give the best results in terms of washing fastness. In addition, when the color fading was examined in the evaluation made after the washing fastness test, it was determined that the color did not fade in all prints.

printing times of 60 seconds and 120 seconds in sublimation prints with 30 seconds printing time and washing fastness is even better than long-term prints.

\section{References}

Akkaya, M., \& Eyupoglu, S. (2016). The examination of the effects of quercus aegilops extract used as natural mordant on colourfulness features of natural dyeing. In 2016 IEEE NW Russia Young Researchers in Electrical and Electronic Engineering Conference (EIConRusNW) (pp. 108-111). IEEE.

Bae, D. G. (2020). Effect of Cyanoethylation Pretreatment on the Sublimation Transfer Printing of Cotton Fabric. Textile Coloration and Finishing, 32(3), 135-141.

Brady, P. R., Cookson, P. G., Fincher, K. W., \& Lewis, D. M. (1980). Sublimation transfer printing of wool.

Cahill, V., \& Ujiie, H. (2004). Digital textile printing 2004. Presentation, VCE Solutions, Philadelphia University, Salt Lake City, UT.

Glombikova, V., \& Komarkova, P. (2014). Study on the Impact of Dye-Sublimation Printing on the Effectiveness of Underwear. Tekstilec, 57(2).

Guan, Y., Mao, Y. H., Zheng, Q. K., Zheng, G. H., \& Tian, T. (2009). Transfer printing with disperse dyes on cotton fabric modified with an aqueous tolylene diisocyanate derivative. Fibers and Polymers, 10(4), 488-495.

Hayta, P., Oktav, M., Ateş, Ö., \& Özomay, Z. Preparation of Ecofriendly Offset Printing Ink Varnish with Safflower Oil and 
Pinus pinaster Resin and Printability. Anadolu Orman Araştırmaları Dergisi, 6(2), 62-67.

Hsieh, M. C., \& Lin, J. S. (2018). Study on design of temperature-dependence of sublimation transfer roller. In MATEC Web of Conferences (Vol. 185, p. 00036). EDP Sciences.

ISO 105-C06, Test for Colour Fastness of Textiles-Colour Fastness to Washing.

Jin, H., \& Sturm, J. C. (2010). Super-high-resolution transfer printing for full-color OLED display patterning. Journal of the Society for Information Display, 18(2), 141-145.

Özomay, M., \& Akalın, M. (2020). Optimization of Fastness Properties with Gray Relational Analysis Method in Dyeing of Hemp Fabric with Natural and Classic Mordant. Journal of Natural Fibers, 1-15.

Özomay, Z., (2009). IGT Test Baskı Makinesi ile Ofset Bask1 Makinesi Arasındaki Renk Uyumu için Optimum Prosedürün Hazırlanmas1. Marmara Üniversitesi Fen Bilimleri Enstitüsü, Yüksek Lisans Tezi, İstanbul

Qihong, C., \& Qinghua, M. (1997). Study of the Technology of Heat Transfer Printing on Cotton Fabric [J]. Journal of Wuhan Textile Sht Institute, 2.

Salem, A. A., Shahin, M. F., El Sayad, H. S., \& El Halwagy, A. A. (2013). Transfer Printing Of Polyester Fabrics With Natural Dyes. Research Journal Of Textile And Apparel.

Sönmez, S., Uzun, M., \& Akgül, A. (2019). Printability of Bamboo Jersey Fabrics in Thermal Transfer Printing
System. International Journal of Advances in Engineering and Pure Sciences, 31, 104-107.

Stojanović, S., Geršak, J., Trajković, D., \& Cirković, N. (2020). Influence of sublimation transfer printing on alterations in the structural and physical properties of knitted fabrics. Coloration Technology.

Şahin, C., Özomay, Z., Keskin, B., (2013). Gazete Kağidinda Baski Basincinin Nokta Kazancina Etkisinin Değerlendirilmesi. Ejovoc (Electronic Journal of Vocational Colleges), 3 (3), 121128.

Ural, E., Özomay, Z., \& Özdemİr, L. (2018). Determination of the effect of palm oil ink on print quality. Mus Alparslan University Journal of Science, 6(1), 533-537.

Wu, Y. J., \& Bai, R. (2011). Color reproduction capability on $100 \%$ cotton fabrics using dye-sublimation heat transfer printing. In NIP \& Digital Fabrication Conference (Vol. 2011, No. 1, pp. 41-44). Society for Imaging Science and Technology.

Yongqing, L. (2014). Development of sublimation transfer printing on natural fabrics. Textile Dyeing and Finishing Journal, 36(8), 10-13.

Zelenkova, T. N., Kozlova, O. V., Shirmanova, V. V., \& Khakhin, S. N. (2020). Application of Acrylic Polymers in Transfer Printing of Cotton Fabrics. Russian Journal of General Chemistry, 90(9), 1777-1780. 